\title{
USING ENGLISH AS A MEANS OF INSTRUCTION (EMI) IN TEACHING CONTENT SUBJECTS
}

\author{
Syariful Muttaqin ${ }^{1}$, Ismarita Ida ${ }^{2}$ \\ Brawijaya University Malang ${ }^{12}$ \\ smuttaqin@ub.ac.id $^{1}$, ismarita_ida@ub.ac.id $^{2}$
}

\begin{abstract}
A foreign language will be more effectively learned when integrated with content rather than isolated as a learned subject; thus the language should be more used in contexts than just formally learned. Recent language teaching methods have been geared toward involving both content and language teaching simultaneously, referred as CLIL, CBI, EMI or L2 use. This article is aimed at describing the use of L2 in teaching content subjects by looking at the attitudes of the students and the interaction between students and teachers at a university in Indonesia. Using mixed research method by conducting survey and nonparticipant observation to obtain the data about the classroom interaction and attitudes of the students in EMI classes, this study reveals that students' attitude towards EMI classes is at a moderate to high level. The classroom interaction has been mostly done in English. Both the students and the lecturers use English in the classroom when they are involved in activities up to a certain level for content understanding. In addition, it is common to find code mixing or code switching during interaction. This can be due to their awareness of the benefits and advantages of having more English interaction in this program.
\end{abstract}

Keywords: L2; attitude; interaction.

\section{INTRODUCTION}

Despite the increasing debate in the use of English as means of instruction or EMI (Coleman, 2006), more universities are promoting EMI as a breakthrough to prepare their students to be ready for globalization. This can be due the belief that a foreign language will be more effectively acquired if it is integrated with content rather than learned in isolation as a school subject (Blanton, 1992; Geneese, 1994). In other words, English should rather be used in 'real' contexts than just learned formally. As stated by Krahen (1983, cited in Lightbown \& Spada, 2006) that there are two process, namely acquisition as a "natural" way of developing knowledge of a second language and learning as a conscious process where conscious rules about a language are developed. Of the two, acquisition process is seen to be more effective (Genesee, 1994; Chin \& Chien, 2003). Consequently, recent language teaching methods have been geared toward involving both content and language teaching simultaneously.

In Indonesia, however, most schools still teach English separately as a foreign language subject to be learned from elementary schools to universities. As a compulsory subject, it is only given just two up to four class hours per week. In addition, the position of English as a foreign language has made it difficult for English learners to get more exposure outside the 
class which is important in learning a foreign language. These are the reasons why English language teaching in Indonesia is still considered as a failure (Sadtono, 2005).

Actually, some efforts have been done to improve ELT in Indonesia shown by continuously improving curriculum since the independence of Indonesia up to the current applied curriculum which is communicative language teaching approach (Sadtono, 2005). Recently, in order to promote more effective use of English for non-English students, some efforts have been made by using English as a means of instruction rather than as a learned subject, such as promoting bilingual teaching and content based learning in ESP classes (Kasbolah, 2005; Sadtono, 2005; Muttaqin, 2009). By integrating English into content subject teaching it is hoped to provide a greater chance of fulfilling the need of mastery of both content and English.

Up to now however, there have been few comprehensive studies in the use of English as a means of instruction in Indonesian tertiary educational contexts despite the fact that English has been a great demand and has been gaining more attention than before. This article is aimed at describing the attitudes of the students toward EMI program and the interaction between students and teachers in EMI classes at an Indonesian university.

\section{REVIEW OF LITERATURE}

EMI policy has encouraged international co-operation and interaction in various education fields and is also helping to influence cultural awareness and learning abilities (Crystal, 2003). Theoretically, using English at schools as a means of instruction rather that as a taught subject has been supported by many scholars. Learners should be given opportunity to use the language in more real life. Also, learners should be provided with comprehensible input to process the language acquisition (Lightbown \& Spada, 2006). In general, old saying says, practice makes perfect.

Up to now, there have been many schools in Indonesia offering bilingual or even English only programs, ranging from the prestigious schools in Jakarta such as Pelita Harapan, Global Jaya, Bina Nusantara High, Gandhi Memorial International School to schools in local level either state/public or private ones. They offer various international program, from adopting international curriculum, such as Cambridge, Singaporean, or even Australian curriculum (Santoso, 2006). Some have also developed their curriculum by having collaboration with some universities for their curriculum development. In addition, school facilities and learning material along with teacher training and expert teacher hiring are among the efforts to ensure the international classes are run as expected. However, despite the high cost and energy spent 
for the internationalization, some reports have indicated that the result in terms of content and language mastery is still questionable (Santoso, 2006)

Some studies have shown that the requirements and conditions for ideal international standard high school have not be fulfilled yet, such as the proportion of EMI due to topic difficulty, students' background of English, class size, teacher's confidence, and length of teaching experience (Handayani, 2011). To support the EMI program, some programs have also been done, such as utilizing ICT optimally, promoting team teaching accompanied with facilitator as well as native speaker, designing class activities by giving individual assignment, discussion in group, as well as discussion before the class (Suwardani, 2009)

At tertiary education level, some studies have shown that the language gain varies depending on the proficiency level with lower beginning students' significant increase and the satisfactory level of content mastery, but no significant correlation between English proficiency and language mastery (Pattiradjawane, 2009). In addition, classroom interactions are geared toward more student-centred with more group discussion and classroom presentation in most of the EMI classes (Muttaqin, 2009).

In Malaysia, the policy to initiate the use of EMI was intended to address the problem of difficulties by the university graduates to get a job due to lack of ability to speak English well which is also supported by the Federation of Malaysian Manufacturers (Zaaba et.al., 2011). It began in 1993 when the Malaysian Prime Minister Mahathir Mohamad set the policy to implement English as a medium of instruction for science and technology courses in public higher education institutions supported by Education Act of 1996 which allowed English to be used as the medium of instruction in private higher education institutions. Following this, some universities in Malaysia started to apply EMI for all science and technology courses. Moreover, to enroll in universities there, students had to take Malaysia University English Test (MUET). To support the higher education policy in using EMI, the government announced the implementation of teaching science and mathematics in English at the primary and secondary levels of education in 2003. However, as time passes, some problems then have occurred in the implementation since the EMI policy did not involve higher education institutions in the decision making. The aim to improve the English proficiency has not been achieved yet. EMI classes seem to be struggling to fully use English, rather teachers prefer to apply code mixing or switching in class interaction (Ariffin \& Husin, 2011). This is done because the teachers try to assure the understanding of content and also their lack of English proficiency. However, students perceive this differently that is those who have low English 
see this as a help, but those who are good in English think that this even lower their English skills.

In their effort to face global world, Taiwan has also been under tremendous pressure from this trend towards academic internationalization by introducing English-medium instruction in higher education (Coleman, 2006) in order to attract both local and international students. A study in a Taiwanese university which compared two classes with different EMI, one using Mandarin and the other English, has shown that in terms of grades obtained, there was no obvious difference, but the class with EMI tended to show a more positive learning attitude and also felt that their proficiency in English for the four skills had been improved (Wu, 2006), despite some disadvantages of EMI reported that English-medium instruction caused greater difficulties in understanding the course content and inhibited them from expressing themselves fluently in the class.

Another study by Chang (2012) at a Taiwanese university which requires all undergraduate students in the three major colleges to complete at least 18 credits of EMI subject courses before graduation shows that English was used more than $90 \%$ of the class time in only a minority of the courses carrying the label of "English-medium instruction." In the class it is shown that in class, there were often found code switching from English to Mandarin during the class under the following circumstances: (1) when students looked confused; (2) when students asked for an explanation in Mandarin; and (3) when the concept introduced was difficult. In addition, it also found that for various reasons (such as large class size, limited class time and students' poor writing and speaking abilities), the lecturers usually just "encouraged" their students to try to speak English in class and to answer their test questions in English, rather than forcing them to do so to reduce students' anxiety level. In terms of content and language mastery, about one third $(32.3 \%)$ of the students reported that instruction in English not only helped their learning of the subject content, but also helped them improve their English language proficiency, and overall, most of the students thought that instruction in English helped them improve their English language proficiency. The low students' lecture comprehension derived from the fact that the subjects taught in English were in themselves difficult, difficulties they had with the English language, such as limited vocabulary. In terms of interaction, it is found out that very few students asked questions in class, even when most of them looked confused during the lectures causing the teachers to be less able to determine students' specific problems and difficulties in order to adjust their lectures in a timely manner. This may in turn further impede students' comprehension of the lectures. 
Another term used related to EMI is content based instruction (CBI). In addition to immersion program applied in Canada, some studies on CBI at tertiary level (mostly quasiexperimental or descriptive in nature), has found out that CBI has benefited learners in all level of education with a variety of acquisition contexts. The benefits are: (1) enhanced foreign language competence; (2) enhanced subject matter knowledge; (3) enhanced selfconfidence in their ability to comprehend and use the target language; and (4) enhanced motivation to continue foreign language study beyond the requirement. (Dupuy, 2000, cited in Dalton-Puffer, 2011).

In Europe, Coleman (2006) states that many content and language integrated learning (CLIL) projects have shown how students improved their subject knowledge and target language proficiency. A good example country is Austria, where this bilingual concept has been successfully introduced in several Austrian schools. There are some positive results learned from the EMI implementation (Haagen-Schützenhöfer \& Mathelitsch, 2001). Students instructed with EMI show an enhanced flexibility in foreign-language communication and they are able to talk about a large variety of subject-specific topics in which subject-specific topics are explained more slowly and on a simpler linguistic level, which often contributes to a deeper subject understanding. In addition, the instruction of content subject through the medium of a foreign language often increases students' motivation. Finally, the use of a foreign language frequently avoids the confusion between everyday concepts and scientific concepts. The EMI method makes it easier for students to acquire scientific concepts as there is usually no temporal gap between the acquisition of a term and the matching scientific concept.

According to Haagen-Schützenhöfer \& Mathelitsch (2001), some points need to be considered, however, to assure the successful implementation of the program, such as the ability and motivation of students, the shortage of science teachers who have a profound knowledge of English poses another problem, a lack of continued education, which would prepare science teachers for the instruction with EMI, a shortage of adequate teachingmaterials (their language is too difficult or their scientific content is far under students' cognitive level and thus bores them)

In addition, there are some criticism that that in real practice, the implementation of this approach is often different from the policy design (Evans, 2009, cited in Dalton-Puffer, 2011) where it is often difficult to assure that English-medium instruction can really benefit tertiary students studying their subject courses in a variety of acquisition contexts. 


\section{RESEARCH METHOD}

This research was conducted to see how EMI as a teaching approach was implemented in a faculty at an Indonesian university. This faculty is selected since it has officially initiated the international class (English class) by having some policies: using English as a means of Instruction, having international program, either double degree or foreign students.

Since this study was aimed at describing: the interaction between students and teachers and the attitudes of the students a mixed method was applied. To collect the data, survey was conducted to obtain data about the interaction of the students and the lecturers. In addition, to complement the survey, interviews and non-participant observation were done to obtain data especially about classroom interaction and attitudes of the lecturers and the students. The data are: (1) students and teachers' responses about the attitudes and interaction, (2) voice recording of the classroom interaction and teacher and student language, (3) documents about curriculum, faculty profile, and some of the students works, such as assignments, (4) and students' language proficiency test.

The quantitative data were analyzed using statistical procedure using SPSS and simple Excel Program to obtain interpretation of the data and generate findings about the attitudes and interaction of the students in EMI program and qualitative data were analysed qualitatively to describe patterns, themes, models and phenomena about the implementation EMI.

\section{RESULTS AND DISCUSSION}

\section{Results}

This part presents the research finding of this study which cover the attitudes of the students toward EMI program, the interaction between students and teachers in EMI classes, and the students' language learning strategies in taking EMI program.

Before getting into the detailed finding of the study it is necessary to show the general description of the students which covers the students' interest and their language proficiency. The finding shows that the students have the level of interest in learning English is 4.3 (scale of 1 -5) which indicates that in general the International Program students have very high level of interest in learning English. This is supported by the finding that the level of English proficiency by self rating is mostly at the intermediate level. The detail level of proficiency level is shown in the table below:

Table 1: Self Rating of Proficiency Level of Students 


\begin{tabular}{lc}
\hline Advanced & 5,3 \\
\hline Upper intermediate & 19,3 \\
\hline Intermediate & 49,1 \\
\hline Pre-intermediate & 8,8 \\
\hline Beginner & 17,5 \\
\hline
\end{tabular}

However, it is quite surprising that the Beginner level students account for $17.5 \%$ of the respondents which lead to a question about their ability in following the classes using English.

In addition, the respondents' effort in improving their English through joining English course is low shown by the data that $68.4 \%$ respondents do not join any English courses, only $31.6 \%$ join English courses. In preparing and reviewing their lessons the respondents state that they do not prepare and review course materials written in English as shown in the table below.

Table 2: Text Preparation and Reviewing of the Students

\begin{tabular}{lll}
\hline English text & 36,8 & 36,8 \\
\hline Indonesian Text & 21,1 & 17,5 \\
\hline Mixed & 42,1 & 45,6 \\
\hline
\end{tabular}

\section{Students' attitudes towards EMI program}

The students' perception is classified based on three aspects: understanding of the course materials, difficulty level, and benefits of taking international program class using English as a means of Instruction.

\section{Students' perception on course understanding}

The student's perception on course understanding is shown in the following table.

Table 3.The perceptions of students on EMI

\begin{tabular}{lc}
\hline $\begin{array}{l}\text { EMI class makes students easy to grasp information about their } \\
\text { discipline }\end{array}$ & 3,5 \\
\hline $\begin{array}{l}\text { Students find it difficult to understand learning resources, } \\
\text { learning materials, texts used in EMI class }\end{array}$ & 3 \\
\hline $\begin{array}{l}\text { EMI class makes students left behind by those students learning } \\
\text { in Indonesian class }\end{array}$ & 2,6 \\
\hline
\end{tabular}

From the table above, it can be seen that the level of understanding by the students is not high (3.5). They also state that the understanding difficulty in learning materials used in EMI class is at a moderate level (3.04). However, when it is compared between the degree of achievement of the students at International program and that of the regular class, the data indicate that the international program students are not left behind from the regular students. 


\section{Students' perception of the disadvantages of using EMI}

The students' perception on the disadvantages of EMI class is shown in table below.

Table 4. Students' Perception on the Disadvantages of EMI

\begin{tabular}{lc}
\hline Students find EMI class adding their burden: & 2,7 \\
\hline $\begin{array}{l}\text { EMI class makes students difficult to memorize terms and } \\
\text { concept in English }\end{array}$ & 2,9 \\
\hline $\begin{array}{l}\text { EMI class hinders students participation in expressing ideas } \\
\text { and opinions in class }\end{array}$ & 2,4 \\
\hline $\begin{array}{l}\text { EMI class hinders classroom interactions between students } \\
\text { and teachers }\end{array}$ & 2,5 \\
\hline
\end{tabular}

From the table it is shown that the students see EMI class does not disadvantage the students in terms of the burden (2.6), concept understanding (2.9), hindrance in classroom participation (2.4) and student-teacher interaction (2.5).

\section{Students' perception on the advantages of EMI class}

The students' perception on the advantages of EMI class is shown the table below.

Table 5. Students' Perception on the Advantages of EMI

\begin{tabular}{lc}
\hline EMI class influences their achievement positively & 3,5 \\
\hline $\begin{array}{l}\text { Students are more motivated because English is used in real life } \\
\text { situations }\end{array}$ & 3,8 \\
\hline $\begin{array}{l}\text { Students have more opportunities to practice their English better in } \\
\text { EMI classes }\end{array}$ & 3,9 \\
\hline $\begin{array}{l}\text { English used can help students improve their cognitive/academic } \\
\text { skills in English (developing concepts, thinking, reasoning, planning, } \\
\text { and problem solving) }\end{array}$ & 3,9 \\
\hline $\begin{array}{l}\text { Students can use the informations from EMI class in their academic } \\
\text { activities creatively }\end{array}$ & 3,5 \\
\hline $\begin{array}{l}\text { Students can follow news related to their discipline from medias (TV, } \\
\text { radio, magazines, newspapers, and internet) using English }\end{array}$ & 3,7 \\
\hline
\end{tabular}

From the table it can be seen that students show not high level of advantages in terms of motivation (3.8), opportunities to practice English in EMI class (3.9), cognitive/academic improvement (3.9), creative use of information for academic activities (3.5), and ability to follow media in English (3.7).

\section{Classroom Interaction}

In this section interaction is defined by how English is used in the classroom interaction. Firstly, it is intended to show how teachers use English in teaching and learning activities. The finding of how the use of English by the teacher is shown below. 
Table 6. Lecturers' Use of English in Classroom Interaction

\begin{tabular}{lc}
\hline Use of English by lecturers in favourite class: & 3,9 \\
\hline Use of English by lecturers in not favourite class: & 3,4 \\
\hline Teacher's encouragement in using English & 4,1 \\
\hline $\begin{array}{l}\text { Teachers requirement to use English in asking, presenting, and } \\
\text { doing assignment }\end{array}$ & 4,1 \\
\hline The fluency of lecturers in delivering class in English: & 3,8 \\
\hline $\begin{array}{l}\text { Teachers' use of Indonesian to avoid misunderstanding of the } \\
\text { students: }\end{array}$ & 4 \\
\hline
\end{tabular}

From the table we can see that the teachers' level of use and fluency of English in the international program is high (3.4 - 3.9) which means that the range of use is $75 \%-89 \%$ in their class. In addition, the teachers also encourage their students to use English at high level (4 of 5) which means that the teachers really pay high attention to the students' use of English. However, the students also think that although the use of English is required in the international program, the use of Indonesian is highly needed to support the understanding of the lectures.

Table 7.Students' Use of English in Classroom Activities

\begin{tabular}{lc}
\hline Use of English by students in class: & 3,1 \\
\hline Use of English in Exam (UTS/UAS): & 4,5 \\
\hline Making notes using English: & 3,9 \\
\hline $\begin{array}{l}\text { Students' participation in discussions using English } \\
\text { confidently: }\end{array}$ & 3,5 \\
\hline $\begin{array}{l}\text { Students' confidence and fluency in asking questions using } \\
\text { English in EMI class }\end{array}$ & 3,7 \\
\hline Students cannot answer exams well if using English & 2,4 \\
\hline
\end{tabular}

From the table above it can be seen that the use of English by the students in classroom interaction fall at the medium level of use (3.1). In exam the use of English is at a high to very high level (4.5). In addition, in following the class, the students also take notes using English at a high level (3.9). The Students' level of confidence is medium to high level (3.5). The level of confidence is shown to be quite high level of confidence (3.7).In addition, they do not agree that they cannot answer well in exams if using English.

From the table 8 , it can be seen that the level of understanding of the students in following the explanation of the lecturers using English in international program is nearly high (3.8 of 5). However, they also nearly agree (3.4 of 5) that sometimes they also miss or misunderstand the lecturers' explanation. Thus, the level of ability to retell the materials explained by the lecturers is not quite high (3.4). In addition, their ability in summarizing 
course materials and answering questions either in written or oral form is at a moderate level. In the difficulty level of understanding the answers given by the lecturers, they answer it neutrally (3 of 5). Overall the mastery of the course materials is at a moderate level (3.3)

Table 8. Understanding of Students on the Course

\begin{tabular}{lc}
\hline Level of understanding of the students in EMI class: & 3,8 \\
\hline $\begin{array}{l}\text { Students sometimes miss or misunderstand the course materials } \\
\text { delivered in English }\end{array}$ & 3,4 \\
\hline Students ability to retell the materials explained by lecturers: & 3,4 \\
\hline $\begin{array}{l}\text { Students have no difficulty in summarizing course materials } \\
\text { using English in EMI class: }\end{array}$ & 3,1 \\
\hline $\begin{array}{l}\text { Students find difficulties in answering questions in written } \\
\text { form: }\end{array}$ & 3,1 \\
\hline $\begin{array}{l}\text { Students find difficulties in answering questions in spoken } \\
\text { form: }\end{array}$ & 3,1 \\
\hline $\begin{array}{l}\text { Students find difficulties in understanding answers given by } \\
\text { lecturers: }\end{array}$ & 3 \\
\hline $\begin{array}{l}\text { Students ability to master the course materials by the methods } \\
\text { used by the lecturers: }\end{array}$ & 3,3 \\
\hline
\end{tabular}

\section{Discussion}

The international program is aimed at developing students in the subject content and English language in order to be able to compete in international competition. This requires some standards for goal achievement. However, as seen from the finding, the students level of English is mostly at an Intermediate level. This means that at this level the use of English is still at a limited range. Surprisingly, some of the students even state that their English is still at the beginner level. From this finding it is suggested that the interaction in the classroom will not be as smooth and effective as expected. Therefore, most of the students agree that the lecturers are expected to do some code switching or mixing during the class to assure that the students can understand well.

In terms of students' attitude it can be seen that their level of understanding is at a moderate to high (agree) level. This level indicates that the students have not been comfortable with the teaching and learning process. The aforementioned level also indicates that there are some aspects to be considered, such as the lecturers' language competence and also teaching methods.

However, from the data it is shown that the students do not see EMI program as a hindrance for language learning. Most students do not agree that the EMI program should be blamed for the unsuccessful. This can be supported by the finding that most students feel that the lecturers are expected to switch to Indonesian language or even the students can switch to 
Indonesian language when interacting in class. In other words, the students mostly have positive enough perception on the application of EMI. They hope that the this program will benefit academically and professionally in terms of English language and content subject mastery.

In classroom interaction, it is shown that the level of use of English by the lecturers is not high yet, This should be addressed to the fact that not all lecturers have sufficient English competence to be used in explaining the materials. Thus, it is also found that the use of Indonesian is still permitted and expected to assure that the understanding of content is achieved. However, the lecturers are active in encouraging or suggesting students to use English in class interaction.

From the students' side it is shown that their level of English use is also not as high as expected. This can be seen from the fact that based on the finding, their English background is still at the intermediate level. Only few students have advance or Upper Intermediate level of English. The finding also indicates that the beginner level of students are still quite many so that the expectation of a full English program should be carefully designed and monitored so the intended aims can be achieved.

Having all the findings above, it can lead to the students' level of understanding during classroom interaction. Their understanding of the course explanation by the lecturers have not reach up to high level, it is still medium to high level. There are some factors that can cause this. First, is the lecturers' competence in English is not at a required level, thus affecting the students understanding. Then, the students' level of competence in English is still mostly at a moderate level. This means that some programs in increasing the language competence of both the students and the lecturers should be designed to help both the lecturers transfer the information fluently and comprehensively and also the students accept a better level of understanding at the International Program.

As the goals of International Undergraduate Program that is to produce the graduates who have strong competencies in the economics and business and to equip them with professional skills which enable them to survive in a global business environment, the international students are obliged to use English as the medium of communication. It is expected that by having good communication in English, the graduates will have a capacity to compete in the globalization era.

Then, since International Undergraduate is the member of AACSB International (The Association to Advanced Collegiate School of Business) USA, it allows this program to collaborate with colleagues around the world. This cooperation encourages international 
students to cross border to take undergraduate study either by taking double degree or student exchange program. Those which are offered by the International Undergraduate Program can be the motivation and the goals of the students to be international students in which English is used in the teaching and learning activity.

Besides, from the background questionnaire result, it implies that the international students also have high motivation to learn English due to the interest in its language, interest in its culture, and the need of English for future career. Therefore, those motivations encourage the students to choose metacognitive strategies as the strategies most frequently used since these strategies help the students achieve learning goals by managing, arranging, and planning their own learning. This finding is in line with the statement of Politzer (cited in Muttaqin, 2008, page 47) that Asian students are high in using instrumental motivation in which English in International Undergraduate Program is used as the medium of instruction in teaching and learning process.

Next, in the International Undergraduate Program, all courses are taught in English. Since there are differences in the linguistics aspects such as the vocabularies, language rules, writings system, words spelling, and pronunciations, they can be the problems in their learning process. Moreover, it is possible that the students make some errors in producing English since English is not their mother tongue. Therefore, metacognitive strategies are useful for the students to cope with those problems successfully by monitoring their errors. Thus, it can help the students for directing the learning process in a more efficient and effective way. Therefore, the application of metacognitive strategies must be considered very crucial in learning process, as stated by O'Malley et al (1985, cited in O'Malley and Chamot, 1990, page 99) "students without metacognitive approaches are essentially learners without direction and ability to review their progress, accomplishments, and future learning directions".

Based on the finding and analysis there are some conclusions derived in accordance to the research problems of this study. Students show moderate to high level of attitudes about the EMI program at the International Program at FEB. This can be due to their awareness of the benefits and advantages that they can get by joining this program. This level of perception needs to be increased up to higher level in order that the students can participate well in classroom. This can be done by developing more teaching and learning methods for assisting students and teachers in accomplishing the course objective using English as EMI.

The classroom interaction has been mostly done in English. Both the students and the lecturers use English in the classroom when involved in activities up to a certain level for 
content understanding. Since the level of English competence is still not high, it is common to find code mixing or code switching during classroom interaction. The students expect that this is done by the lecturers because by only using English the level of understanding of the content cannot be guaranteed.

Based on the conclusion, it is suggested that the faculty of Economics and Business can further develop the lecturers and students' English competence by having pre-service or inservice training. This training is to help the lecturers deliver the course content in English well and the students can follow the class better. In addition, the lecturers should support the students language development by paying necessary attention to the students' language to help students improve their language, in terms of the pronunciation, the grammar, and vocabulary, etc. Further studies should be conducted on the use of English as a means of instruction by having focusing on the students and lecturers' language and see how the language competence can have relationship with the content mastery.

\section{REFERENCES}

Ariffin, K. \& Husin, M.S. (2011). Code-Switching and Code-Mixing of English and Bahasa Malaysia in Content-Based Classrooms: Frequency and Attitudes The Linguistics Journal, June 2011, Volume 5 Issue 1.

Blanton, L. L. (1992). A Holistic Approach to College ESL: Integrating Language and Content. ELT Journal Volume 4613.Oxford University Press.

Chang. (2012). English-Medium Instruction for Subject Courses in Tertiary Education: Reactions from Taiwanese Undergraduate Students. Taiwan International ESP Journal, Vol. 2: 1, 55-84.

Chin, G. \& Chien, W. (2003). Integrating English into an Elementary School Life Course, The Internet TESL Journal, vol. IX, no. 12. viewed 3 April 2007, http://iteslj.org/Articles/.

Coleman, J. A. (2006). English-Medium Teaching in European Higher Education. State-ofthe-Art Article. Lang. Teach. 39, 1-14. doi:10.1017/S026144480600320X . Cambridge University Press, UK.

Crystal, D. (2003). English as a Global Language, (2nd Ed.), Cambridge: Cambridge University Press.

Dalton-Puffer, C. (2011). Content-and-Language Integrated Learning: From Practice to Principles? Annual Review of Applied Linguistics, 31, 182-204.C Cambridge University Press, 0267-1905/11 doi: 10.1017/S0267190511000092.

Genesee. (1994). Integrating Language and Content: Lessons from Immersion. NCRCDSLL Educational Practice Reports, Center for Research on Education, Diversity and Excellence, UC Berkeley.

Haagen-Schützenhöfer, C. \& Mathelitsch, L. (2001). English as a Medium of Instruction in Science-Teaching. Institute for Theoretical Physics, University of Graz, Austria. 
Handayani, R. (2011). English as a Medium of Instruction Used by Mathematics and Science Teachers at Pre-International Standard Senior High School. (Unpublished Thesis) Program Pascasarjana UM, Malang.

Kasbolah, K. (2005). Bilingual Programmes in Indonesia: What do the Projects Tell Us? Conference Proceeding. TEFLIN Conference, UAD Yogyakarta.

Lightbown, P. \& Spada, N. (2006). How Languages are Learned. Oxford University Press. Oxford.

Muttaqin, S. (2009). Integrating English into Content Subject Teaching in Indonesian University: Toward Strengthening ESP Course. Conference Proceeding. COTEFL UMP Purwokerto.

O’Malley, J. M., \& Chamot, A. U. (1990). Learning Strategies in Second Language Acquisition. Cambridge: Cambridge University Press.

Pattiradjawane, A. M. (2009). The Implementation of Bilingual Education at Klabat University and its Outcomes as Seen in Students' English Proficiency and Their Achievement in Subject-Matter. (Unpublished Dissertation). Program Pascasarjana UM. Malang.

Sadtono, E. (2005). A Concise History of TEFL in Indonesia. TEFLIN Conference Proceeding. UAD Yogyakarta.

Santoso, T. (2006). The Benefits of Bilingual Education and its Applications in Indonesia. Jurnal Pendidikan Penabur - No.06/Th.V/Juni 2006.

Suwardani, N. P. (2009). Implementasi Kebijakan Rintisan Sekolah Bertaraf Internasional (Studi Multisitus pada Tiga Sekolah Menengah Atas Negeri di Bali). Unpublished Thesis. Program Pascasarjana UM, Malang.

Wu, W.-S., (2006). Students' Attitude Toward EMI: Using Chung Hua University as an Example. Journal of Education and Foreign Language and Literature, 4, 67-84. TIESPJ, Vol. 2: 1, 2010.

Zaaba, Z., Aning, I. N. A., Gunggut, H., Ramadan, F.I.M., Umemoto, K. (2011). English as a Medium of Instruction in The Public Higher Education Institution: A Case Study of Language-in-Education Policy in Malaysia (Selected Topics in Education and Educational Technology). School Of Knowledge Science. Japan Advanced Institute of Science And Technology. 6-115 Jaist Student Housing, 1-8 Asahidai, Nomi Shi, 9231211, Ishikawa Japan 